\title{
Open Educational Resources: Challenges and Opportunities in Indian Primary Education
}

\author{
$1 \sqrt{2}$ \\ Janani Ganapathi \\ Queensland University of Technology, Australia
}

\begin{abstract}
Education is a fundamental human right, yet one fifth of the world's population lives with poor literacy. India is home to the largest number of illiterate people, with infrastructural, cultural, and socio-economic factors hindering equitable access to quality education. Due to the rapidly growing technology and Internet usage in the country, open educational resources (OER) are increasingly being used as a vital tool to help transcend barriers to child literacy, also aiding in educational attainment. While an array of scholarly works provides evidence of the potential in OER to influence higher education outcomes in developing nations, academic analysis of their impact on primary level education attainment has been minimal. This paper retrieve lessons from three children's content providing organizations to understand the opportunities and challenges of OER in primary-level education in developing nations with similar cultural, infrastructural, and socio-economic issues. While the findings of this study suggest that the use of OER allows for greater distribution and scale across different cultural and linguistic settings, particularly in rural and remote regions, they also warn against the adaptation and pedagogical barriers of OER into societies where traditional modes of education are established and trusted.
\end{abstract}

Keywords: open educational resources, literacy, language, access, equity, distribution, pedagogy, teacher training 


\section{Introduction}

Educational attainment is a persistent challenge for many countries with low levels of literacy (Paran \& Williams, 2007). In the particular case of India, home to the oldest education system (Sharma \& Sharma, 1996) and with one of the largest tertiary education systems (World Bank, 2007), it is also the country with the highest number of illiterate persons (UNESCO, 2014). Like most developing nations, poor school attendance and dropout rates are depriving Indian children from the acquisition of literacy (Mukherjee \& Das, 2008), hence impacting progress and completion of primary education. This is common in countries with multicultural and multilingual communities (MacKenzie, 2009), which often lack sufficient pedagogic support for linguistic acquisition (Gelda, Narayan, Mudiyam, Raturi, \& Seshan 2013; Nambeesan, 1996). Access to resources and distribution channels are also a major problem for developing countries like India (Rai, 2014), requiring for a modification in policies and actions in order to pave way for equitable educational expansion (Govinda \& Bandyopadhyay, 2010).

With the rapid growth of an information society, and the diffusion of information technology, new methods of learning have also increased, paving the way for alternate solutions for learning. A decade ago, a study led by the Organization for Economic Co-operation and Development (OECD) detailed this opportunity, identifying that new modes of learning and teaching also challenge established perceptions and practices of how education and the act of educating need to be organized and transmitted. The study had also emphasized that these new mediums could bring a change to the way learning happens, where most educational resources are protected by passwords and proprietary systems, restricting access to those outside the "paywall" (Organization for Economic Co-operation and Development [OECD], 2007). In the years that followed this study, the OER movement gained increasing recognition for its potential to overcome such barriers, and release this "contained" knowledge freely for the benefit of all, encouraging the equitable and widespread diffusion of resources. OER continue to receive increased global attention, especially due to their use by large institutions like the Massachusetts Institute of Technology (MIT), with multiple countries adopting them in their tertiary sectors (Van Acker, Vermeulen, Kreijns, Lutgerink, \& Van Buuren, 2014; Stacey, 2010).

OERs are defined as materials available in the public domain for use in learning, teaching and research purposes. They are usually released under an open license, which allows free use or repurposing by the public (Tuomi, 2013), OER enable a multi-directional flow of knowledge (Conole, 2012). While openness in education has successfully established itself as a latest alternative option to acquiring knowledge (Weller, 2013), this success should be viewed as a water drop in the ocean of what openness entails (Scanlon, 2012). OER present certain challenges to educational practice at the literacy and primary education level, which providers need to address. They are not fully self-directed and therefore the requirement of tutors in online or classroom settings cannot be overlooked (Salter, 2011; Doğan \& Eby, 2014). Another issue is that there currently are two divergent learning models attempting to co-exist: the OER model, which promotes independent learning, and the traditional education model, where the role of the institution is more explicit, as with MIT's OpenCourseWare. (Knox, 2013).

Yet, the promise of OER's potential in bridging the gap between formal and informal knowledgetransmission has been acknowledged and embraced by governments and independent organizations with the objective of widening participation in education (D'Antoni, 2009). However, while the 
adoption of such non-traditional educational mediums into mainstream education poses challenges for both primary and tertiary sectors, much of the existing scholarly works have been on tertiary education. This has created a need for attention toward the different challenges for primary education (Geith \& Vignare, 2008) that include, but are not limited to, the need for teacher training, which is the key enabler of OER utilization in classrooms (Whitworth, McIndoe, \& Whitworth, 2011; Van Acker, Van Buuren, Kreijns, \& Vermeulen, 2013).

This paper analyzes the experiences of three OER-providing case study organizations; the State Council of Educational Research and Training (SCERT), Pratham Books, and Siyavula, to explore the important role that OER can play in improving literacy rates and primary education attainment in multicultural and multilingual developing countries. In particular, this study engages with the innovative ways in which the case study organizations balance the need to sustain their business model and social mission, whilst acknowledging that OER will not be the standalone solution to revolutionize primary education in the developing world.

\section{Methodology}

This paper is the outcome of a doctoral research, which undertook an in-depth multiple case analysis, as prescribed by eminent methodologist Stake (2005), of three children's content providers to understand the role and the ways in which OER could potentially impact primary education in developing countries. The study engaged with respondents from three prominent organizations: the State Council of Educational Research and Training (SCERT) (Tamil Nadu state, South India), Pratham Books (India), and Siyavula (South Africa), to gather state, national, and international level perspectives, respectively. The multiple case study design was used for this research, in order to identify, analyze, and synthesize the patterns, similarities, and differences across the three organizations' use of OER for literacy and primary level education. The motivation behind this choice was to probe the outcome of such a use, the methods employed, as well as to retrieve novel or divergent themes from the contrasting of the three cases.

At each organization, semi-structured interviews of staff involved in the creation and dissemination of OER were carried out. The individuals interviewed consisted of staff from different levels of hierarchy such as editors, social media managers, and chairpersons. The size of each organization and the availability of staff limited the total number of interviews to 11. However, the respondents that took part in the study largely helped in comprehending each organization's objectives, achievements, challenges, and development goals. As a result, saturation was achieved in each organization and it could be confirmed that every interview strengthened the prior understanding held about the organizations, without contradicting earlier ideas.

As part of the ethical clearance procedure, formal consent was obtained from the three organizations through formal letters and participant information and agreement forms. The interview questions were prepared to cover the respondents' views on OER, the opportunities, barriers, impact on literacy and primary education, intellectual property challenges, and funding, amongst others. Conducted at the convenience of the interviewees, mostly in their offices, the interviews generally lasted 1 to 2 hours. Naturalistic observation was also a part of the data collection phase, especially in the case of SCERT and Pratham Books, where subtle observation on work environment and behavior were taken 
note of for a better interpretation of the results. Unlike SCERT and Pratham Books, wherein face-toface interviews were conducted, naturalistic observation was not applicable to Siyavula since the interviews were held over Skype.

The inductive analysis method was utilized for data interpretation through the drawing of themes and concepts (Thomas, 2006). This method increased the robustness of results because it permitted each case study to be examined both independently and as a data source. The latter served in structuring and interpreting the meanings drawn from each data source (Thorne, 2000), allowing comparison between the case studies (Thomas, 2003). Inductive analysis also permitted a comparative analysis between the preconceptions and findings (Eisenhardt \& Graebner, 2007; Yin, 1994), assisting in developing comprehensive knowledge about each organization and OER provision. More specifically, Creswell's (2012) six-step process was followed for the data analysis procedure. Following the collection, preparation and organization of data for analysis through the translation and transcription of audio recordings and notes, the data was thoroughly examined and coded to identify the themes. The three dominant themes that emerged were language, literacy, and culture; access, distribution, and pedagogy; and user-generation, quality, and sustainability. The first two themes form the main discussion of this paper, through the lens of the OER-providing three case study organizations.

\section{Findings}

The results of this study cover some of the main themes that emerged, in relation to the opportunities and challenges for OER in Indian primary education: language and literacy; access, equity, and distribution; and pedagogy and teacher training. The findings reveal the complex interrelationships between these themes, which collectively determine the success of OER in this area.

\section{Language, Literacy, and OER}

Language acts as a major barrier to literacy and thereby education, in countries where numerous cultures, faiths, and language groups coexist (Cobo, 2013; Torres, 2013). As a result, in multilingual nations like India, catering resources in all existing languages has thus far been a serious challenge.

We have 22 official languages in India but we have about 150 other languages spoken by people, in which very little publishing happens. And also within the 22 official languages, there are disparities. ...In a single language environment... you know, if you are in a western country and you speak only English, the amount of resources you'll get in English will be huge. Also if you see, the distribution of languages. ... Often, the smallest languages are spoken by the poorest communities so there is often no incentive to produce in that language. Why would a publisher go into a tribal language when nobody is buying the books there? (Singh, Pratham Books)

Linguistic diversity is therefore a significant barrier to the efforts in addressing the educational requirements (MacKenzie, 2009) of indigenous communities and minority language groups, given the complexities involved. Often, resource creators also have to bear in mind the different cultural combinations the language groups could present, affecting reception and use of the created content. 
So, the difficulties come in many forms. The major one is the language. If you are writing about a boy who goes to school, which language are you going to write the story in? (Kumar, Pratham Books)

Here for example, in Kanyakumari [a Tamil Nadu district], there are Keralites [people belonging to the neighboring state of Kerala] and in Krishnagiri [a Tamil Nadu municipality], there are Kannadigas [people belonging to the neighboring state of Karnataka], so what do we do? In Chittoor [a district in Andhra Pradesh that borders Tamil Nadu], there are Telugu people. In Ranipet [a suburb of Vellore, Tamil Nadu], there are Urdu people. So, what would we do in such a situation? (Kuppusamy, SCERT)

OER providers like Pratham Books have found that OER have the potential to cater to multiple languages and cultural sensitivities at the same time (Nyaga \& Anthonissen, 2012; Asfaha, Beckman, Kurvers, \& Kroon, 2009). While their OER platform allows the creation and translation of content in numerous languages and scripts, they also provide bilingual and multilingual resources tailored to certain communities. The following extract explains the case of literacy resources created by Pratham Books for tribal children located in the Indian state of Odisha.

Both the texts are in Odia but one is in their local language, because it doesn't have a script and one is in Odia, so that way it helps. If they know what the story is in their own language, then they can understand what it is in Odia also. So we did this in four tribal languages (Hemant, Pratham Books)

For [a] community to develop mother tongue literacy, they need resources in their languages. We are now a text-based world. Unless every single person can negotiate text ... you won't be able to negotiate the new world. Therefore, having reading skills is critical... And really, this starts from mother tongue literacy. So, once you have mother tongue literacy, then you can learn other languages and subjects. (Singh, Pratham Books)

Based on the experiences and initiatives of the case study organizations of this research, which are largely invested in creating online multilingual resources and offline distribution strategies, it can be understood that OER stand a significant chance of impacting minority language groups in acquiring literacy through mother tongue education in rural and remote areas of a country like India.

I think the term that we are using very often now is in "online-offline" strategy. ... While creation happens online, consumption will happen offline, in most cases and we have structured strategies for that. (Shah, Pratham Books)

This "online-offline" creation and distribution strategy is especially crucial to developing nations where educational and technological infrastructure are inadequate (Kumar, 2009; Khanna \& Basak, 2013) and access to resources (Bossu \& Willems, 2012) by rural communities continues to depend on the distribution of printed materials. The forthcoming sub-section explores this in the context where access to technology may be unevenly available and where a focus on increasing or improving distribution channels may not be sufficient to challenge the existing inequitable outcomes. 


\section{Access, Equity, Distribution, and OER}

One of the key causes for pushing creation and consumption to take place on digital platforms is the prevailing distribution challenge that is at the epicenter of the need for greater and more equitable access to education and educational materials (Blackman, 2016). Open platforms, for instance, permit self-paced learning and vocational training facilities at the community level, furnishing socially required skills for underserved populations (Das, 2011). This creates an opportunity for OER to contribute towards the fulfillment of primary education goals, as described by the following interviewees.

You have so many children in so many schools without access to quality resources. ... I think [OERs] is a great way to kind of give kids who wouldn't have that opportunity otherwise to be able to read or view content, I think there a massive potential for that in India. (Raman, Pratham Books)

OER-providing organizations approached for this research demonstrated their commitment to open education through initiatives that go beyond the mere provision of online content. They utilize a range of strategies to address barriers to access, infrastructure, technology, and equitable distribution of education and educational content, which are specific to the context of literacy and primary education in developing nations, and hence, may not be applicable to developed nations or tertiary education.

I do think that people need to take the context into account. So, solutions [technology] built in America are just not going to work in the developing world. So, they could but they typically are designed for high-infrastructure, well-resourced environments. (Horner, Siyavula)

And, I think [OER] do have the potential but a lot of infrastructural [problems] need to be resolved. (Raman, Pratham Books)

The provision of a well-equipped learning environment with the latest educational technologies can have a transformative effect. Nevertheless, technology proves to be a disruptive innovation, in addition to the costs it brings. (Jain, Sharma, \& Shelly, 2012). The case study organizations maintain a balance between online content provision, traditional print resources, as well as a number of other methods to produce content without or with little cost at the source. These resources are offered to end-users for free in flexible formats through download and print options, as well as through partnerships with community members, schools, and volunteers who act as the direct distributors.

One of the central reasons for the growing interest in OER use is their capacity to increase access to educational content across India, through the enabling of established new distribution channels, especially in the rural regions.

If [we wanted to distribute] beyond the metros and Tier-1 towns [cities with population above 100,000], there are no established distribution channels. ... So, distribution is a huge challenge. Over the years...we have simply gotten more innovative to find distribution solutions. (Singh, Pratham Books)

Almost $70 \%$ of the Indian population is concentrated in rural areas with poor connectivity. Conventional distribution channels are failing to reach children beyond the urban areas, requiring providers' innovative thinking in creating novel distribution pathways. (Baral, 2012). In such 
circumstances, OER have been able to make a major impact even on the most remote and violenceinflicted areas, as exemplified by the below respondent.

Even, there was this person [volunteer] who was living in ... this place where there were a lot of Naxalites [Indian Communist (Maoist) guerrilla groups] and the parents actually send these children to something called a Porta Cabin, so their studies are not hindered by all the violence that is happening. ... He downloaded the book [OER] and then he projected it, and then he was reading to more than 100 children. ... Sometimes people enjoy doing it so much that they have now become storytellers, have their own initiatives [and] have libraries. (Hemant, Pratham Books)

The number of internet and mobile device users have been feverishly rising in developing nations like India, with large number of users on social networking platforms (Palackal et al., 2011; Singh \& Gill, 2015), which could explain why users from such regions access open platforms to print resources for use. The potential of this shift is not lost in the case study organizations, which see themselves at the forefront of providing innovative, alternative, and cost-effective solutions for literacy and primarylevel education achievements into the future.

It is primarily a resource thing, in terms of reach, we don't have the resources so online is our primary means. ... Essentially, it is very expensive. ... Even cost of production and royalties removed, the cost of printing and distributing is very high. So, essentially, what we are able to do as a small organization is to make these available online and then do advocacy around people who got the resources to print and distribute: governments, large funders, donors, etc. (Horner, Siyavula)

In all cases, these dissemination modes are run with a thorough understanding of the differences between target audiences and with the mandate of increasing access and equity in mind. However, while the effectiveness of OER may begin with distribution and access in achieving equitable education for the masses, it does not end there. OER and digital technologies are slowly penetrating school classrooms, requiring a paradigm shift in primary education from being teacher-centered and textbook-based to becoming learner-centered, which is a key component in determining the success of OER in such active learning spaces.

\section{Pedagogy, Teacher Training, and OER}

OER are slowly penetrating classrooms in developed countries (Marcus-Quinn, 2016), as well as into developing countries' rural classrooms, as in the case of Sub-Saharan Africa, where teachers are using OER created by the Teacher Education in Sub-Saharan Africa (TESSA) Consortium (Murphy \& Wolfenden, 2013). As noted by the respondents of this research, a similar trajectory has also been observed in classrooms across countries such as South Africa and India. Government bodies like SCERT as well as individual organizations like Siyavula and Pratham Books are working directly with teachers to encourage their understanding of OER and the adoption of OER into teaching.

I think it is really exciting when open educational resources start to impact teaching and learning practices ... [and] open educational practices. And specifically, so we have done a lot of collaborative authoring with teachers where we get teachers involved in the creation of open educational resources and that could be your foundational resource but then, the benefit and the potential of that resource can be adapted and built upon. (Beckett, Siyavula) 
We have seen some teachers create flash cards as well, on the platform. So, that is another way of actually bringing different topics into the classroom and reading comprehension for sure. (Singh, Pratham Books)

The literature also supports the potential of OER in helping teachers develop practices and competencies required for efficient teaching, in parallel to which they are believed to support teachers in creating classrooms suitable to the needs of students (Misra, 2014). Most importantly, teachers can develop the necessary knowledge and skills to use OER effectively through training, in addition to which they can learn to produce their very own (Misra, 2012), allowing the fulfilment of student needs as well as providing teachers with the opportunity to become knowledge creators in their own right (Muegge, Mora, Hassin, \& Pullin, 2008). However, teachers often lack technology knowledge and OER awareness, which are crucial for the adoption and success of OER.

And, I think a lot of them, especially, for more senior teachers, there is the fear of technology as well. "How do I use this?" and you know, "this is something I don't know" and all of that is there. So, a lot of training and hand-holding there. (Raman, Pratham Books)

I think the teachers over here don't necessarily know what OER is .... That is a term that we understand in use but for them it is "resources." (Shah, Pratham Books)

For these reasons, the case study organizations largely engage in advocacy around OER and teacher training. SCERT for instance is dedicated to training teachers to use OER and classroom technologies for pedagogical improvements. However, it is revealed that there are a number of challenges in integrating OER into rural school systems.

There are problems in taking [OER] to the village-level. Taking this to the grassroots-level presents several problems. If you see, the students and the public schools will know of the availability of such resources only if the school headmasters repeat about the existence of such resources over and over again. ... So, a lot has to be done in this space. Till today, there continues to be a number of disadvantages. (Kuppusamy, SCERT)

On the OER side, it is complicated. I think we are at a formative sort of stage. Essentially OER represent something of a paradigm shift and we are still in the shifting stage. (Horner, Siyavula)

The case study organizations recognize that continued advocacy around such resources and justification for the use of new teaching methods are required to eradicate poor awareness and skepticism amidst school teachers, school management, and parents. "The movement toward greater openness represents a change of philosophy, ethos, and government as well as a set of interrelated and complex changes that transform markets, altering the modes of production and consumption" (Peters, 2012, p. 1041). The traditional teaching and learning method continues to be the most trusted and recognized method of education, because of which a change in such an established system could be time-consuming.

Traditional learning will always have some place or some part in how we learn and how our children learn. I don't think, unless you go to a very very ... alternative, really really far left kind of leaning organization and you enroll your children there but for the kind of children we are talking about, I think there will always be an element of root learning, an element of 
examination, in their lives. But I think you know the resources we give them to learn with, I think that can be revolutionary. (Raman, Pratham Books)

I think ... that [OER] can be truly transformative, both in traditional classrooms and in a digital environment. So, personally, I think they can have a massive impact in helping teachers do their jobs better, helping facilitating sharing, and then improving the quality of education for specific learners. (Horner, Siyavula)

The adoption of novel classroom technologies and learning mediums could impact student learning outcomes, breaking down traditional governance structures and teacher-centered education models (Kanwar, Kodhandaraman, \& Umar, 2010). Moreover, in the absence of evidence to prove that the use of OER could have a negative influence on student performance, "the attitudinal response that OERs improve factors relating to student performance, such as enthusiasm, engagement and confidence represent a strong case for their adoption" (Weller et al., 2015, p. 359) by education providers such as schools and teachers.

\section{Conclusion}

This study disclosed some of the most significant barriers to the full implementation and widespread use of OER in developing countries like India for the attainment of primary level education goals. The in-depth analysis of the three selected case studies of SCERT, Pratham Book, and Siyavula, in conjunction with the support of scholarly works in the area, revealed that language, illiteracy, poor accessibility, diversity, inequity, lack of sufficient distribution channels, lack of teacher training, and teacher-centered education are major contributing factors to the slowing down of OER adoption to address the basic education needs of the young population. Alongside the challenges, the results also showed optimism about the potential of OER in addressing the existing gaps.

In concurrence with the existing literature, this research found that the difficulties involved in teaching multilingual children could be overcome if digital technologies and OER could be absorbed into primary school classrooms (Thakrar, Zinn \& Wolfenden, 2009; Wolfenden, Buckler, \& Keraro, 2012) and if new educational policies endorsed mother tongue literacy (Nyaga \& Anthonissen, 2012). Even though schools are starting to incorporate OER into teaching (Hennessy, Haßler \& Hofmann, 2016; Marcus-Quinn, 2016), there are a number of oppositions and constraints that persist, mainly due to OER being viewed as contesting the traditional education system and textbook publishers (Kowalski, 2008; Białecki, Jakubowski, \& Wiśniewski, 2017). The case study organizations have demonstrated thorough understanding of the key needs of child literacy and primary level education in showing that the success of an OER-providing model relies on their continuous generation and involvement in initiatives such as capacity building and advocacy around the harnessing of OER, as well as the combination of both online and offline consumption strategies.

The increasing usage and generation of OER are not only useful to the citizens of the country of origin but are also being used in other countries around the world (Natarajan, 2011), as in the case of Pratham Books and Siyavula, whose resources have been largely utilized in neighboring nations. Although OER have the capacity to impact the underserved populations by breaking the barriers to distribution and access, scholars also warn against some pitfalls that can be caused by access-focused OER provision models. More precisely, they suggest in order to achieve educational equity, it is primordial to leave aside the distracting quantitative outlook and focus on qualitative aspects, such as 
innovation and quality assurance, which future research should bear in mind. (Bossu \& Willems, 2012). The present research provides an early guideline to how OER fit in the context of Indian primary education and the precautions for future OER providers to observe.

\section{Acknowledgements}

The author is greatly indebted to Professor Belinda Carpenter, her former Ph.D. supervisor for making this research possible through the immense support and guidance provided, as well as to the Queensland University of Technology's (QUT) Law Faculty for their generosity in funding this work by providing the author with a Write-Up Scholarship (2017). This article is derived from a thesis submitted in partial fulfillment of the requirements for the degree of Doctor of Philosophy to QUT, Australia in August 2017. 


\section{References}

Asfaha, Y. M., Beckman, D. M., Kurvers, J. J. H., \& Kroon, S. (2009). L2 reading in multilingual eritrea: The influences of L1 reading and English proficiency. Journal of Research in Reading, 32(4), 351-365. doi:10.1111/j.1467-9817.2009.01399.x

Baral, D. (2012). Redefining rural marketing: An approach towards micro entrepreneurship with special reference to Shakti. Asian Journal of Multidimensional Research, 1(4). Retrieved from

http://www.tarj.in/images/download/ajmr/AJMR\%20SEPTEMBER September\%202012\%2 OPAPERS\%2OPDF/AJMR\%2OSEPTEMBER\%202012\%20PAPERS\%2OPDF/9.15,\%20Dr.\%2 oS.K.\%20Baral.pdf

Białecki, I., Jakubowski, M., \& Wisniewski, J. (2017). Education policy in Poland: The impact of PISA (and other international studies). European Journal of Education, 52(2), 167-174. doi:10.1111/ejed.12216

Blackman, C. (2016). Content creation and distribution in the digital single market. Info, 18(6), 1-3. doi:10.1108/info-07-2016-0032

Bossu, C., \& Willems, J. (2012). Equity considerations for open educational resources in the globalization of education. Distance Education, 33(2), 185. doi:10.1080/01587919.2012.692051

Cobo, C. (2013). Exploration of open educational resources in non-english speaking communities. The International Review of Research in Open and Distributed Learning, 14(2), 106-128. doi: http://dx.doi.org/10.19173/irrodl.v14i2.1493

Conole, G. (2012). Fostering social inclusion through open educational resources (OER). Distance Education 33(2), 131-134. doi: https://doi.org/10.1080/01587919.2012.700563

Creswell, J. W. (2012). Educational research: Planning, conducting, and evaluating quantitative and qualitative research (4th ed.). Boston: Pearson.

D'Antoni, S. (2009). Open educational resources: Reviewing initiatives and issues. Open Learning: The Journal of Open, Distance and e- Learning, 24(1), 3-10. doi:10.1080/02680510802625443

Das, A. (2011). Emergence of open educational resources (OER) in India and its impact on lifelong learning. Library Hi Tech News 28(5), 10-15. https://doi.org/10.1108/07419051111163848

Doğan, T. G., \& Eby, G. (2014). Constructing a flexible distance learning environment through a sociotechnical perspective. International Journal of Information Communication Technologies and Human Development (IJICTHD), 6(4), 47-66. doi:10.4018/ijicthd.2014100105

Eisenhardt, K. M., \& Graebner, M. E. (2007). Theory building from cases: Opportunities and challenges. Academy of Management Journal, 5o(1), 25-32. doi:10.5465/AMJ.2007.24160888 
Geith, C., \& Vignare, K. (2008). Access to education with online learning and open educational resources: Can they close the gap? Journal of Asynchronous Learning Networks, 12(1), 105. Retrieved from https://eric.ed.gov/?id=EJ837472

Gelda, A., Narayan, V., Mudiyam, M., Raturi, K., \& Seshan, N. (2013). Needs improvement: Despite progress, India's primary education system has a ways to go. Pennsylvania: The Wharton School.

Govinda, R., \& Bandyopadhyay, M. (2010). Social exclusion and school participation in India: Expanding access with equity. PROSPECTS, 4O(3), 337-354. doi:10.1007/s11125-010-9160-8

Hennessy, S., Haßler, B., \& Hofmann, R. (2016). Pedagogic change by Zambian primary school teachers participating in the OER4Schools professional development programme for one year. Research Papers in Education, 31(4), 399-427. doi:10.1080/02671522.2015.1073343

Jain, D., Sharma, S., \& Shelly, G. (2012). Problem and aspects of technology in higher education (with special reference to professional courses). International Journal of Management Research and Reviews, 2(9), 1584.

Kanwar, A., Kodhandaraman, B., \& Umar, A. (2010). Toward sustainable open education resources: A perspective from the global south. American Journal of Distance Education, 24(2), 65-80. doi:10.1080/08923641003696588

Khanna, P., \& Basak, P. C. (2013). An OER architecture framework: Need and design. International Review of Research in Open and Distance Learning, 14(1). doi:10.19173/irrodl.v14i1.1355

Knox, J. (2013). Five critiques of the open educational resources movement. Teaching in Higher Education, 18(8), 821-832. doi:10.1080/13562517.2013.774354

Kowalski, E. (2008). Representations of linguistic and ethnocultural diversity in Poland's education policy, national school curricula and textbooks. Journal of Multilingual and Multicultural Development, 29(5), 364-379. doi:10.1080/01434630802147874

Kumar, M. S. V. (2009). Open educational resources in India's national development. Open Learning: The Journal of Open, Distance and e-Learning, 24(1), 7784. doi:10.1080/02680510802627860

MacKenzie, P. J. (2009). Mother tongue first multilingual education among the tribal communities in India. International Journal of Bilingual Education and Bilingualism, 12(4), 369-385. doi:10.1080/13670050902935797

Marcus-Quinn, A. (2016). The potential of high-quality open educational resources (OERs) for the teaching of English poetry. Journal of Poetry Therapy: The Interdisciplinary Journal of Practice, Theory, Research, and Education, 29(1), 33-45.

doi:10.1080/08893675.2016.1133085 
Misra, P. K. (2012). Training teachers to use and produce open educational resources: A win-win approach. I-Manager's Journal of Educational Technology, 9(2), 1-8. Retrieved from https://eric.ed.gov/?id=EJ1102031

Misra, P. K. (2014). Online training of teachers using OER: Promises and potential strategies. Open Praxis, 6(4), 375-385. doi:10.5944/openpraxis.6.4.155

Muegge, S., Mora, M., Hassin, K., \& Pullin, A. (2008). A flat network for the unflat world: Open educational resources in developing countries. Open Source Business Resource. Retrieved from: http://search.proquest.com/docview/1695038717/

Mukherjee, D., \& Das, S. (2008). Role of parental education in schooling and child labour decision: Urban India in the last decade. Social Indicators Research, 89(2), 305-322. doi:10.1007/s11205-007-9233-0

Mukhopadyay, B. (2016). Understanding cashless payments in India. Financial Innovation, 2(1), 126. doi:10.1186/s40854-016-0047-4

Murphy, P., \& Wolfenden, F. (2013). Developing a pedagogy of mutuality in a capability approach: Teachers' experiences of using the open educational resources (OER) of the teacher education in Sub- Saharan Africa (TESSA) Programme. International Journal of Educational Development, 33(3), 263-271. doi:10.1016/j.ijedudev.2012.09.010

Nambeesan, G. B. (1996) Equity in education? Schooling of Dalit children in India. Economic and Political Weekly, 31(16/17). Retrieved from https://www.jstor.org/stable/4404063

Natarajan, M. (2011). Exploring the e-resources for educational use. International Journal of Information Dissemination and Technology, 1(4), 193. Retrieved from http://search.proquest.com/docview/1041348293/

Nyaga, S., \& Anthonissen, C. (2012). Teaching in linguistically diverse classrooms: Difficulties in the implementation of the language-in- education policy in multilingual Kenyan primary school classrooms. A Journal of Comparative and International Education, 42(6), 863-879. doi:10.1080/03057925.2012.707457

Organization for Economic Co-Operation and Development. (2007). Giving knowledge for free: The emergence of open educational resources. Paris: OECD. Retrieved from: http://www.oecd.org/education/imhe/38947231.pdf

Palackal, A., Nyaga Mbatia, P., Dzorgbo, D., Duque, R. B., Ynalvez, M. A., \& Shrum, W. M. (2011). Are mobile phones changing social networks? A longitudinal study of core networks in Kerala. New Media \& Society, 13(3), 391-410. doi:10.1177/1461444810393900

Paran, A., \& Williams, E. (2007). Editorial: Reading and literacy in developing countries. Journal of Research in Reading, 30(1), 1-6. doi: 10.1111/j.1467-9817.2006.00334.x

Peters, M. A. (2012). User created education. Educational Philosophy and Theory, 44(10), 1041-1044. doi:10.1111/j.1469-5812.2011.00818.x 
Rai, A. (2014). Implementation of the RTE act: RTE Forum's stocktaking report. Social Change, 44(3), 439-449. doi:10.1177/0049085714536806

Salter, L. (2011). Preconditions for post-employment learning: Preliminary results from ongoing research. International Review of Research in Open and Distance Learning, 12(1), 24-41. doi: http://dx.doi.org/10.19173/irrodl.v12i1.888.

Scanlon, E. (2012). Open educational resources in support of science learning: Tools for inquiry and observation. Distance Education, 33(2), 221. https://doi.org/10.1080/01587919.2012.692053

Sharma, R. N., \& Sharma, R. K. (1996). History of education in India. New Delhi: Atlantic Publishers \& Distributors.

Singh, K. P., \& Gill, M. S. (2015). Role and Users' Approach to Social Networking Sites (SNSs): A Study of Universities of North India. The Electronic Library, 33(1), 19-34. doi:10.1108/EL-122012-0165

Stacey, P. (2010) Foundation funded OER vs. tax payer funded OER - A tale of two mandates. Barcelona: ED 2010 Proceedings. Retrieved from http://openaccess.uoc.edu/webapps/o2/bitstream/10609/5241/6/St acey editat.pdf

Stake, R. E. (2005). Qualitative case studies. In N. K. Denzin \& Y. S. Lincoln (Eds.), The Sage Handbook of Qualitative Research (3rd ed., pp. 443-466). Thousand Oaks, CA: Sage.

Thakrar, J., Zinn, D., \& Wolfenden, F. (2009). Harnessing open educational resources to the challenges of teacher education in Sub-Saharan Africa. International Review of Research in Open and Distance Learning, 1O(4). doi: http://dx.doi.org/10.19173/irrodl.v10i4.705

Thomas, D. R. (2003). A general inductive approach for qualitative data analysis. School of Population Health, University of Auckland, New Zealand. Retrieved from http://www.fmhs.auckland.ac.nz/soph/centres/hrmas/ docs/Inductive2003.pdf

Thomas, D. R. (2006). A general inductive approach for analyzing qualitative evaluation data. American Journal of Evaluation, 27(2), 237-246. doi:10.1177/1098214005283748

Thorne, S. (2000) Data analysis in qualitative research. Evidence-Based Nursing, 3, 68-70. doi:10.1136/ebn.3.3.68

Torres, N. P. M. (2013). Embracing openness: The challenges of OER in Latin American education. Open Praxis, 5(1), 81-89. doi:10.5944/openpraxis.5.1.33

Tuomi, I. (2013). Open educational resources and the transformation of education. European Journal of Education, 48(1), 58-78. doi:10.1111/ejed.12019

UNESCO. (2014). Teaching and learning: Achieving quality for all. Education for All (EFA) Global Monitoring Report (GMR) 2013/4. Retrieved from http://unesdoc.unesco.org/images/0022/002266/226662e.pdf 
Van Acker, F., Van Buuren, H., Kreijns, K., \& Vermeulen, M. (2013). Why teachers use digital learning materials: The role of self-efficacy, subjective norm and attitude. Education and Information Technologies, 18(3), 495-514. doi:10.1007/s10639-011-9181-9

Van Acker, F., Vermeulen, M., Kreijns, K., Lutgerink, J., \& van Buuren, H. (2014). The role of knowledge sharing self-efficacy in sharing open educational resources. Computers in Human Behavior, 39, 136-144. doi:10.1016/j.chb.2014.07.006

Weller, M. (2013). The battle for open - A perspective. Journal of Interactive Media in Education, 2013(3). doi: http://doi.org/10.5334/2013-15

Weller, M., De Los Arcos, B., Farrow, R., Pitt, B., \& McAndrew, P. (2015). The impact of OER on teaching and learning practice. Open Praxis, 7(4), 351-361. doi:10.5944/openpraxis.7.4.227

Whitworth, A., Mcindoe, S., \& Whitworth, C. (2011). Teaching media and information literacy to postgraduate researchers. ITALICS Innovations in Teaching and Learning in Information and Computer Sciences, 1O(1), 35-42. doi:10.11120/ital.2011.10010035

Wolfenden, F., Buckler, A. S. H., \& Keraro, F. (2012). OER adaptation and reuse across cultural contexts in Sub Saharan Africa: Lessons from TESSA (teacher education in Sub Saharan Africa). Journal of Interactive Media in Education, 2012(1), 3. doi: http://doi.org/10.5334/2012-03

World Bank. (2007). Country summary of higher education: India. Retrieved from http://siteresources.worldbank.org/EDUCATION/Resources/2782001121703274255/1439264- 1193249163062/India CountrySummary.pdf

Yin, R. K. (1994). Discovering the future of the case study method in evaluation research. Evaluation Practice, 15(3), 283-290. doi:10.1016/o886-1633(94)90023-X 